\title{
Molecular and Cellular Characterization of Human CD8 T Suppressor Cells
}

\author{
Zheng Xu, Sophey Ho, Chih-Chao Chang, Qing-Yin Zhang, Elena-Rodica Vasilescu, \\ George Vlad and Nicole Suciu-Foca*
}

Immunogenetics and Cellular Immunology, Department of Pathology and Cell Biology, Columbia University, New York, NY, USA

\section{OPEN ACCESS}

Edited by:

Fernando A. Arosa,

University of Beira Interior, Portugal

Reviewed by:

Elena Ranieri,

University of Foggia, Italy

Xiongwen Wu,

Tongji Medical College, China

${ }^{*}$ Correspondence:

Nicole Suciu-Foca

ns20@columbia.edu

Specialty section: This article was submitted to T Cell Biology,

a section of the journal

Frontiers in Immunology

Received: 24 August 2016 Accepted: 16 November 2016 Published: 30 November 2016

Citation:

Xu Z, Ho S, Chang C-C, Zhang Q-Y, Vasilescu E-R, Vlad G and Suciu-Foca N (2016) Molecular and Cellular Characterization of Human

CD8 T Suppressor Cells.

Front. Immunol. 7:549. doi: 10.3389/fimmu.2016.00549
Bidirectional interactions between dendritic cells and Ag-experienced T cells initiate either a tolerogenic or immunogenic pathway. The outcome of these interactions is of crucial importance in malignancy, transplantation, and autoimmune diseases. Blockade of costimulation results in the induction of $\mathrm{T}$ helper cell anergy and subsequent differentiation of antigen-specific $\mathrm{CD}^{+} \mathrm{T}$ suppressor/regulatory cells (Ts). Ts, primed in the presence of inhibitory signals, exert their inhibitory function in an antigen-specific manner, a feature with tremendous clinical potential. In transplantation or autoimmunity, antigen-specific Ts can enforce tolerance to auto- or allo-antigens, while otherwise leaving the immune response to pathogens uninhibited. Alternatively, blockade of inhibitory receptors results in the generation of cytolytic $\mathrm{CD} 8^{+} \mathrm{T}$ cells, which is vital toward defense against tumors and viral diseases. Because $\mathrm{CD} 8^{+} \mathrm{T}$ cells are MHC Class I restricted, they are able to recognize HLA-bound antigenic peptides presented not only by APC but also on parenchymal cells, thus eliciting or suppressing auto- or allo-immune reactions.

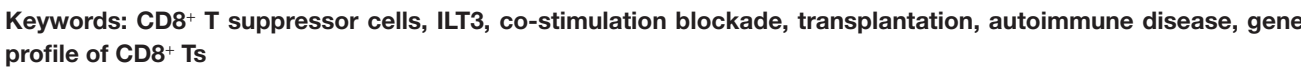
profile of $\mathrm{CD}^{+} \mathrm{Ts}$

\section{INTRODUCTION}

Over the last decade, the prevailing dogma has been that self-tolerance is mediated through dominant suppression of autoimmune responses by regulatory $\mathrm{CD} 4^{+} \mathrm{CD} 25^{+} \mathrm{FoxP}^{+} \mathrm{T}$ cells $\left(\mathrm{CD} 4^{+} \mathrm{Treg}\right)$. Naturally occurring Tregs specifically express the transcription factor FOXP3 (forkhead box P3) (1). Natural $\mathrm{CD} 4{ }^{+} \mathrm{CD} 25^{+}$Treg constitute $5-10 \%$ of peripheral $\mathrm{CD} 4{ }^{+} \mathrm{T}$ cells in normal mice and $<5 \%$ in humans. Their essential role in tolerance was shown by experiments in which the depletion of natural Tregs from the thymus of newborn rodents resulted in enhanced immune responses to conventional bacteria from the intestine. This provoked inflammatory bowel disease (IBD) and the development of autoimmune diseases. In contrast, expansion of Tregs suppressed allergy, organ allograft rejection, graft-versus-host disease after bone marrow transplantation, and various autoimmune diseases $(1-5)$.

The revival of $\mathrm{CD} 8^{+}$suppressor cells $\left(\mathrm{CD} 8^{+} \mathrm{Ts}\right)$ after decades of deliberate omission has been well described in some review articles (6-8). The function of $\mathrm{CD}^{+}$Ts was first documented in the early 80 s by Gershon et al. (9). With the advent of molecular immunology, the existence of the murine I-J locus, presumed to encode Ts function, could not be confirmed. For fear of rejection and denial of grant support, the word "suppressor" was arbitrarily replaced with that of "regulatory" T cells, even 
though the sole function of regulators was to suppress immune function. For this reason, the reader of the suppressor literature would be well advised to search the listing of papers referring to either $\mathrm{CD}^{+}$Treg or $\mathrm{T}$ suppressor cells $\left(\mathrm{CD} 8^{+} \mathrm{Ts}\right)$.

Both $\mathrm{CD}^{+}$and $\mathrm{CD} 4^{+}$Tregs showed similar expression levels of FOXP3 and CTLA-4, which represent their most characteristic markers. On the other hand, the biggest difference between $\mathrm{CD} 4^{+}$ and $\mathrm{CD}^{+}$Tregs resides in the expression of CD28 (10). CD4 ${ }^{+}$ Tregs express a higher level of CD28, which is required for their interaction with B7 molecules. B7 molecules regulate thymic development and peripheral tolerance (11). For $\mathrm{CD}^{+} \mathrm{T}$ cells, the expression of CD28 is partially dispensable due to their reduced production of IL-2 (12-14).

\section{NATURAL AND NON-ANTIGEN-SPECIFIC CD8+ ${ }^{+}$Treg}

Similar to natural $\mathrm{CD}^{+}$Treg, $\mathrm{CD}^{+}$thymus-derived natural Tregs have also been described. Characteristically, these cells have a $\mathrm{CD} 28^{-}$phenotype in both mice and human (15). However, after TCR triggering, both $\mathrm{CD}^{+}$and $\mathrm{CD}^{+}$natural Treg inhibit the immune response in an antigen non-specific and MHC non-restricted manner via direct interaction between Treg and activated T cells. Naturally occurring $\mathrm{CD} 8^{+}$Treg were reported to have a $\mathrm{CD}^{+} \mathrm{CD} 25^{+} \mathrm{CTLA}-4^{+} \mathrm{GITR}^{+} \mathrm{FoxP} 3^{+}$phenotype and suppress in a CTLA-4- and TGF- $\beta 1$-dependent manner (16).

The Qa-1-restricted CD8 alpha, alpha ${ }^{+}$(TCR alpha beta ${ }^{+}$, population is the best characterized population of $\mathrm{CD}^{+}$natural Treg in mice. The Qa-1 molecule (homolog of HLA-E in human) presents peptides derived from the non-hypervariable domain of the TCR. These Vbeta-specific CD8 ${ }^{+}$Tregs interact and inhibit the activation of $\mathrm{CD}^{+} \mathrm{T}$ cells with similar Vbeta regardless of their specificity (17-20).

Study of the miRNA profile of human $\mathrm{CD} 8{ }^{+} \mathrm{CD} 25^{+}$natural Treg revealed 10 differentially expressed miRNAs (miR-214, $-205,-509$ overexpressed and miR-9, -24, -31, -155, -335, -210, and -449 under expressed), which seem to display specific regulation of FOXP3, CTLA-4, and GARP gene expression (21).

Peripheral CD8 ${ }^{+} \mathrm{CD} 28^{-}$Foxp3- CD56- non-antigen-specific Ts were reported to be easily generated and expanded by culturing $\mathrm{CD}^{+} \mathrm{CD} 28^{-} \mathrm{T}$ cells in a cocktail of cytokines containing IL-2, IL-10, and GM-CSF. They were expanded without antigenic stimulation and seemed to inhibit antigen recognition, $\mathrm{T}$ cell proliferation, and cytotoxicity via IL-10 secretion (22, 23). It has been suggested that such Ts can be extracted from patients during disease remission and reinfused during disease exacerbation (24).

\section{ADAPTIVE ANTIGEN-SPECIFIC CD8+ ${ }^{+}$Treg}

Adaptive $\mathrm{CD}^{+}$Ts originate from the post-thymic T cell pool and are induced by a variety of in vivo and in vitro antigenic stimuli. Antigen-specific Treg are required for efficient suppression of $\mathrm{T}$ cell immune responses against MHC-bound peptides derived from auto- or allo-antigens. The best characterized Treg in this category include human $\mathrm{CD} 8^{+} \mathrm{CD} 28^{-}$, $\mathrm{MHC}$ class I-restricted,
T suppressor, and $\mathrm{CD} 4{ }^{+} \mathrm{CD} 25^{+} \mathrm{CD} 45 \mathrm{RO}^{+}, \mathrm{MHC}$ class II-restricted, Treg cells (10). Our previous studies have demonstrated that MHC allo-restricted $\mathrm{CD} 8^{+} \mathrm{CD} 28^{-}$Ts can be generated in vitro by multiple rounds of T cell stimulation in the presence of allogenic APC. Evidence has been provided that Ts develop in vivo from rejectionfree organ allograft recipients. Antigen-specific $\mathrm{CD} 8^{+} \mathrm{CD} 28^{-} \mathrm{Ts}$ exert their function by conditioning APC to become tolerogenic. Our studies on the mechanism of $\mathrm{CD} 8^{+} \mathrm{CD} 28^{-}$Ts-mediated suppression revealed that they act via an APC bridge, inducing the upregulation of immunoglobulin-like transcript (ILT) inhibitory receptors on professional (dendritic cell and monocytes) as well as on non-professional [endothelial cells (EC)] APC (25-29).

\section{CD8 ${ }^{+}$Ts AND ILT3}

The induction of tolerogenic dendritic cells (DCs) was first established in 1998 by our group (26). We showed that human $\mathrm{CD} 8^{+} \mathrm{CD} 28^{-}$Ts cells generated by multiple rounds of in vitro allostimulation interact with APC, inducing the downregulation of co-stimulatory molecules and thereby reducing their capacity to trigger $\mathrm{CD}^{+} \mathrm{T}$ helper $\left(\mathrm{T}_{\mathrm{h}}\right)$ cell activation (27). In the absence of $\mathrm{T}_{\mathrm{h}}$ cell help, $\mathrm{CD}^{+} \mathrm{T}$ cells from the same culture acquire suppressor activity. Similarly, multiple stimulations of human T cells with xenogeneic APC or with peptide-pulsed autologous APC resulted in the generation of antigen-specific $\mathrm{CD}^{+} \mathrm{CD} 28^{-}$Ts cells $(28,29)$. These $\mathrm{CD}^{+}$Ts cells, derived from an oligoclonal population, are MHC class I restricted and express same levels of FOXP3, GITR, CTLA-4, CD25, OX40, CD103, CD62L, 4-1BB, and TNFRII as seen in $\mathrm{CD}^{+} \mathrm{CD} 25^{+}$natural T regulatory (Treg) cells $(10,30)$.

$\mathrm{CD} 8^{+} \mathrm{CD} 28^{-}$Ts can be distinguished from $\mathrm{CD} 8^{+} \mathrm{CD} 28^{-} \mathrm{CTL}$ cells from the same multiple allo-stimulated T cell line (TCL) by the higher expression of some genes from the killer cell inhibitory receptor (KIR) family, such as KIR3DL1, KIR3DL2, and KIR2DL3 and by their gene profile (10).

Upon restimulation with priming $\mathrm{APC}, \mathrm{CD}^{+}$Ts do not produce IFN- $\gamma$, IL-10, TGF- $\beta$, or other cytokines. Instead, $\mathrm{CD}^{+} \mathrm{CD} 28^{-}$Ts inhibit CD40-mediated upregulation of costimulatory molecules, such as CD80 and CD86 on priming APC, which become tolerogenic, upregulating the expression of the inhibitory receptors ILT3 (also called LILRB4, CD85K, or LIR5) and ILT4 (also known as LIR-2, LILRB2, or CD85d). Consequently, APC are rendered unable to induce and sustain the full program of $\mathrm{CD}^{+} \mathrm{T}_{\mathrm{h}}$ cell activation and maturation, due at least in part to inhibition of Nuclear Factor $-\kappa \mathrm{B}(\mathrm{NF}-\kappa \mathrm{B})$ activation and subsequent transcription of co-stimulatory molecules (10, 26-29, 31-34).

Tolerogenic APC can be also generated by exposure of DC to IL-10, IFN- $\alpha$, or IFN- $\beta$, which induce upregulation of ILT3 and ILT4 (14-17, 31-34).

The crucial role of ILT3 and ILT4 was revealed in experiments in which the myelomonocytic cell line KG1 was transfected with ILT3 or ILT4 and used for T cell allo-stimulation. Wild KG1 cells induced strong MLC responses, while ILT3- or ILT4-transfected KG1 cells were non-stimulatory. $\mathrm{CD} 8^{+} \mathrm{CD} 28^{-} \mathrm{T}$ cells from the same cultures inhibited autologous $\mathrm{T}$ cell responses to wild KG1 stimulating cells, displaying suppressor function. $\mathrm{CD}^{+}$ 
$\mathrm{T}_{\mathrm{h}}$ reactivity to KG1-ILT3 or KG1-ILT4 transfectants could be restored by adding to the cultures either anti-ILT3 or ILT4 mAb, respectively, or IL-2. These results indicated that ILT3- or ILT4expressing APC induce T cell anergy and elicit the differentiation of $\mathrm{CD}^{+} \mathrm{CD} 28^{-}$Ts (26).

Allogeneic CD40L-activated pDC (expressing high levels of ILT3 and ILT4) promote the differentiation of naïve CD8 T cells into $\mathrm{CD}^{+} \mathrm{Ts}$. These $\mathrm{CD} 8^{+} \mathrm{Ts}$ inhibit $\mathrm{T}$ cell proliferation via secretion of IL-10 (35).

While overexpression of ILT3 was shown to be a marker of tolerogenicity, knock down of ILT3 augmented the immunogenic capacity of activated DC, significantly increasing their capacity to migrate, produce inflammatory cytokines, and activate IFN$\gamma$ - and IL-17-secreting T effector cells (36).

ILT3 and ILT4 belong to a family of Ig-like inhibitory receptors that are structurally and functionally related to KIRs. Some ILT family members, including ILT2, ILT3, and ILT4, have long cytoplasmic tails containing ITIM. These receptors mediate inhibition of cell activation by recruiting the tyrosine phosphatase SHP-1 (37-40). Coligation of ILT3 and ILT4 in monocytes inhibits $\mathrm{Ca}^{2+}$ mobilization and tyrosine phosphorylation, which is triggered by Ab ligation of FcRII (CD32), HLA-DR, and FcyRI (CD64). The ligand for ILT3 has not been described so far. ILT4 was shown to bind to the $\alpha 3$ domain of HLA class I (HLA-A, HLA-B, HLA-C, and HLA-G), competing with CD8 for MHC class I binding (41, 42). As a result, recombinant soluble ILT4 restores, rather than inhibits, Treg proliferation (43).

Besides the negative signaling that ILT3 transmits endogenously upon ligation, ILT3's extracellular Ig-like domains are also endowed with inhibitory function. This was demonstrated in experiments for which we first engineered the myelomonocytic KG1 cell line (KG1-Delta) to overexpress a signaling-defective ILT3 deletion mutant which lacked the cytoplasmic tail containing ITIM. CD4 ${ }^{+}$T-cell responses in primary and secondary MLC were greatly deficient upon stimulation with these cells, which elicited instead the generation of $\mathrm{CD} 8^{+} \mathrm{CD} 28^{-}$Ts cells. This result suggested that the extracellular domain of ILT3 by itself carries out a tolerogenic function which is independent of the inhibitory intracellular signaling (43). Based on these findings, we engineered a recombinant ILT3.Fc protein, which lacked both the trans-membrane and intracellular domain. When ILT3.Fc was added to T cells at the time of MLC priming, it suppressed CD4 ${ }^{+}$ $\mathrm{T}_{\mathrm{h}}$ cell proliferation and elicited the differentiation of allospecific $\mathrm{CD}^{+}$Ts in vitro as well as in vivo. Hence, both membrane and soluble ILT3 induce CD4 ${ }^{+}$T helper anergy, triggering the generation of $\mathrm{CD}^{+}$Ts cells $(41,44,45)$. This indicates that ILT3 is an essential immune checkpoint or master switch which regulates the outcome of the immune response.

Soluble ILT3, engineered as an ILT3.Fc fusion protein, was shown to induce tolerance to allogeneic human pancreatic islet transplants in humanized NOD/SCID mice (hu-NOD/SCID) (44) and to reverse progression of rejection after its onset (34). ILT3.Fc inhibited both the cellular and humoral arm of rejection, as shown by the inhibition of $\mathrm{T}_{\mathrm{h}} 1$ and $\mathrm{T}_{\mathrm{h}} 2$ proliferation and cytokine production, CTL generation, and synthesis of anti-HLA and xenospecific antibodies by B cells from tolerant animals (34, 44, 46).

\section{GENE PROFILE OF ILT3.FC-INDUCED CD8+ ${ }^{+}$Ts}

ILT3.Fc dramatically changes the landscape of the gene expression profile in $\mathrm{CD}^{+}$Ts cells. Numerous genes in the WNT receptor pathway were significantly upregulated, indicating its important role in the generation of $\mathrm{CD}^{+}$Ts cells. This data support the concept that activation of the WNT pathway inhibits CD8 T-cell proliferation and cytotoxic effector cell differentiation. The expression of TGF- $\beta$ and TGFBR 2 was also significantly increased, consistent with the well-characterized cross talk between TGF- $\beta$ and WNT pathway $(47,48)$.

ILT3.Fc extensively downregulated the expression of cyclins and cyclin kinases while upregulating cyclin-dependent kinase inhibitors. Considering the fact that cyclins and cyclin kinase together with their specific inhibitors are the most important positive and negative regulators in the cell cycle, it is reasonable to assume that ILT3.Fc induces cell cycle arrest, inhibiting T cell proliferation $(47,49)$.

On the gene transcriptional level, ILT3.Fc promotes the expression of transcriptional repressors which block the synthesis of cytokines and other factors necessary for $\mathrm{T}$ cell proliferation and differentiation. The zinc finger transcriptional repressor BCL6 is one of the genes whose elevated expression is important for the differentiation of ILT3.Fc-induced Ts. We found that transfection of BCL6 in allo-activated $\mathrm{CD}^{+} \mathrm{T}$ cells converted them into suppressors, whereas silencing of BCL6 in unprimed T cells prevented their differentiation into Ts when allo-stimulated in the presence of ILT3.Fc. BCL6-transfected Ts share highly similar characteristics with ILT3.Fc-induced Ts both in vitro and in vivo. The in vivo evidence is based on the finding that BCL6 was overexpressed in human $\mathrm{CD} 8^{+} \mathrm{T}$ cells from humanized mice rendered tolerant to pancreatic islet transplants by treatment with ILT3.Fc (34). ILT3.Fc-induced repression of granzyme B, IFN- $\gamma$, IL-5, and enhancement of CXCR4 occurred in conjunction with the upregulation of BCL6 expression in $\mathrm{CD}^{+}$Ts cells. Hence, ILT3.Fc may arbitrate T cell lineage fate through BCL6-mediated repression of $T_{h} 1, T_{h} 2, T_{h} 17$, and CTL and induction of Ts differentiation (34).

MiRNA represents a group of novel regulatory molecules which modulate gene function at the posttranscriptional level. Studies on the miRNA expression profile in ILT3.Fc-induced $\mathrm{CD}^{+}$Ts indicate that they also play a role in the generation of $\mathrm{CD}^{+}$Ts cells. ILT3.Fc inhibited the expression of miR-21, miR30b, and miR-155. Those miRNAs target the $3^{\prime}$-untranslated region of DUSP10, BCL6, and SOCS1, genes whose transcription was highly increased in ILT3.Fc-induced Ts.

Primed CD8 ${ }^{+} \mathrm{T}$ cells transfected with miR- 21 and $30 \mathrm{~b}, \mathrm{miR}-21$ and 155, or miR-21, 30b, and 155 inhibitors displayed suppressor activity when added to autologous CD3-triggered CD4 ${ }^{+} \mathrm{T}$ cells. Luciferase reporter assays of miR-21 and miR-155 indicated that their transcription is highly AP1 dependent, consistent with the finding that for the AP1 subunits, FOSB, and c-FOS, translocation to the nucleus is inhibited by ILT3.Fc. In summary, ILT3. Fc inhibits $\mathrm{T}$ cell activation and induces the generation of Ts by targeting multiple inflammatory miRNA pathways (50). Recent studies on human natural $\mathrm{CD} 8^{+} \mathrm{CD} 25^{+} \mathrm{FOXP} 3^{+} \mathrm{CTLA}-4^{+}$Treg 
cells revealed similar miRNA signatures. The data indicate that miRNAs, including miR-9, $-24,-155$, and -335 , play an important role in the induction of $\mathrm{CD}^{+}$Treg by modulating Treg-associated genes (21).

Studies of exosomes from MLC supernatants revealed the presence of inflammatory microRNA, including miR-146a, miR-155, miR-21, miR-30b, miR-365, and Let-7a. These miRNAs were inhibited when ILT3.Fc was added to the culture, they were produced exclusively by $\mathrm{CD} 4^{+} \mathrm{T}$ cells, being absent from CD4-depleated cultures. Furthermore, upon treatment with exosomes containing inflammatory microRNA, ILT3. Fc-induced $\mathrm{CD}^{+}$Ts lost their suppressive activity at low Ts/T effector cell ratio (51).

MiRNAs contained by exosomes released from allo-activated $\mathrm{T}$ cells enhanced $\mathrm{T}$ helper activity even in the presence of limiting amounts of allospecific T suppressor cells. This suggests that increased amounts of microRNA in recipients' sera may serve as markers of active immune responses against the graft, even in the presence of regulatory $\mathrm{T}$ cells. Furthermore, such exosomes may be of use in eradicating tumors in patients developing lymphoid malignancies secondary to immunosuppression and viral (EBV, CMV, Hepatitis B and C) infections (51).

Comparison of ILT3.Fc-induced $\mathrm{CD} 8^{+}$Ts with $\mathrm{CD} 8^{+} \mathrm{CD} 28^{-} \mathrm{Ts}$ induced in MLC by chronic allogenic stimulation demonstrated that the characteristic signatures of $\mathrm{CD}^{+} \mathrm{T}$ suppressor cells generated by either of these methods are the same, consisting of upregulation of the BCL6 transcriptional repressor and downregulation of inflammatory microRNAs, miR-21, miR-30b, miR-146a, and miR-155. In conclusion, microRNAs, which are increased under inflammatory conditions in activated $\mathrm{CD}^{+}$and $\mathrm{CD}^{+} \mathrm{T}$ cells with helper or cytotoxic function, show low levels of expression in $\mathrm{CD}^{+} \mathrm{T}$ cells that have acquired antigen-specific suppressor activity (52).

\section{CD8 $^{+}$Ts IN TRANSPLANTATION}

The possible role of ILT3 and ILT4 molecules in maintenance of quiescence in transplant patients is of obvious interest. We found that $\mathrm{T}$ cells from heart and liver transplant patients in quiescence, but not from recipients with a history of rejection episodes, induced the upregulation of ILT3 and ILT4 and downregulation of CD80 and CD86 in cryopreserved APC from the donor. As a surrogate for donor APC, DC matched to the donor for at least one HLA class I and one HLA Class II (DR) can be used for flow cytometry and functional assays.

Monitoring of kidney allograft recipients who have been chronically exposed to rapamycin showed increased numbers of DC with the ILT3 ${ }^{+} \mathrm{ILT}_{4}{ }^{+}$tolerogenic phenotype and of $\mathrm{T}$ cells with the $\mathrm{CD} 8^{+} \mathrm{CD} 28^{-}$suppressor phenotype suggesting that mTOR inhibition promotes a novel immunoregulatory pathway (53).

However, since donor DC migrate out of the graft early following transplantation, it was still unclear how quiescence was maintained by some, but not all organ allograft recipients. The most likely explanation seems to be that graft EC, which are non-professional APC that express all donor HLA allo-antigens, become tolerogenic. To explore the possibility that EC are targeted by recipient $\mathrm{CD} 8^{+} \mathrm{CD} 28^{-}$Ts, we transfected umbilical cord EC (matched to the donor for at least one HLA class I antigen) with luciferase ILT3 or ILT4 reporter gene and performed luciferase transcription assay in the presence of recipient $\mathrm{CD} 8^{+} \mathrm{CD} 28^{-}$ T cells. These experiments demonstrated that $\mathrm{CD} 8^{+} \mathrm{CD} 28^{-}{ }^{-}$oxP $3^{+}$ $\mathrm{T}$ cells from the circulation of rejection-free heart transplant patients triggered the expression of ILT3 and ILT4 in EC-sharing class I HLA antigens with the graft. $\mathrm{CD}^{+} \mathrm{T}$ cells from patients with recurrent episodes of acute or with chronic heart allograft rejection did not display ILT3-inducing capacity $(54,55)$. Using cell fractionation and sequencing studies, we further showed that ILT3 precursor RNA are expressed and retained in the nuclei of resting EC. Ts interaction with EC or exposure of EC to IL-10 and IFN- $\alpha$ triggers processing of ILT3 pre-mRNA. Western blot analysis showed that the expression of the mature ILT3 transcript is accompanied by production of ILT3 protein (56). Studies from other laboratories further confirmed our finding that IL-10 also inhibits endothelium-dependent $\mathrm{T}$ cell co-stimulation by upregulating ILT3 and ILT4 in human vascular EC (57).

The tolerogenic role of EC, which express inhibitory molecules, was further explored in a Lewis to ACI rat heart transplantation model. After three injections of UV-irradiated blood from Lewis donors, about $50 \%$ of the ACI recipients became tolerant to donor strain heart transplants. Tolerance could be transferred to secondary ACI recipients by $\mathrm{CD}^{+}$but not by $\mathrm{CD} 4^{+} \mathrm{T}$ cells. Furthermore, the graft of these secondary recipients was tolerated indefinitely even when transplanted to tertiary, non-conditioned $\mathrm{ACI}$ recipients. The $\mathrm{CD} 8^{+} \mathrm{T}$ cells used for adoptive transfer of tolerance were FoxP3 ${ }^{+}$. They induced the expression of PIR-B, a rat ortholog of ILT4, not only in donor APC, but also in the EC lining the aorta of the transplanted heart. Hence, this phenomenon of "graft adaptation" was mediated by the induction of inhibitory receptors in graft EC by MHC Class I allo-restricted $\mathrm{CD}^{+}$suppressor cells (58).

Recently, it was shown that kidney-pancreas transplantation in a type I diabetic patient was characterized by an increased presence of $\mathrm{CD} 8^{+} \mathrm{CD} 28^{-}$Treg in the pancreas and elevated levels of ILT3 expression on APC in a donor-specific manner (59).

Our conclusion that generation of allospecific $\mathrm{CD} 8^{+} \mathrm{CD} 28^{-} \mathrm{Ts}$ may require the induction of anergy in CD $4^{+} \mathrm{T}$ helper cells $\left(\mathrm{T}_{\mathrm{h}}\right)$, e.g., leaving the primed CD8 ${ }^{+} \mathrm{T}$ cells "helpless," is supported by other groups. These investigators used the same MLC stimulation model, but "allo-anergized" $\mathrm{T}_{\mathrm{h}}$ by adding to the MLC a CTLA-4 immunoglobulin fusion molecule (Belatacept) which blocks the CD28-B7 co-stimulation pathway. They further confirmed our finding that repeated rounds of allo-stimulation results in relative and absolute expansion of $\mathrm{CD}^{+}{ }^{+} \mathrm{Foxp}^{+}$Ts. Finally, they found that allo-anergized $\mathrm{CD} 8^{+} \mathrm{CD} 28^{-}$Ts of donor origin are expanded in recipients of allogeneic hematopoietic stem cell transplantation (60). This finding is reminiscent of our and other authors' previous observation that $\mathrm{CD} 8^{+} \mathrm{CD} 28^{-}$Ts are present in the circulation of transplant recipients in quiescence $(26,61-63)$.

Human allo-antigen-specific $\mathrm{CD}^{+}$Tregs were generated in a large scale from antigenically naïve precursors by in vitro stimulation with allogeneic CD40 activated B cells. These cells inhibited GVHD in a humanized mice model, suppressing allo-reactive 
$\mathrm{T}$ cell proliferation and cytokine production by a CTLA-4dependent mechanism (64). In other studies, $\mathrm{CD}^{+} \mathrm{CD} 28^{-}$Tregs were generated in MLC by coculture with mesenchymal stem cells, a method of potential use given the resistance of CD28 ${ }^{-} \mathrm{T}$ cells to treatment with Belatacept, an agent which blocks CD28/ B7 co-stimulation, preventing alloreactivity in kidney transplant recipients (65).

In recent studies, $\mathrm{CD} 8^{+} \mathrm{CD} 28^{-}$Ts cells were generated by multiple MLC simulation and expanded by adding common gamma chain cytokines IL-2, IL-7, and IL-15 to the cultures. The expanded population exhibited increased expression of CTLA-4, FOXP3, and CD25, while the expression of CD56, CD57, CD127, and perforin was downregulated (66). Consistent with our own studies, suppression of $\mathrm{CD} 4 \mathrm{~T}_{\mathrm{h}}$ by $\mathrm{CD} 8^{+} \mathrm{CD} 28^{-}$Ts was HLA class I allo-restricted and cytokine independent. However, the claim that after expansion these cells keep their suppressor function without killing the stimulating APC, as demonstrated in CFSE cytotoxic assays, could not be confirmed in our own studies for which the traditional Cr-51 release from target cells was used. We found that when these cytokines were used for expansion, the proliferating population consisted of CD8 ${ }^{+} \mathrm{CTL}$. It is apparent that rather than being in a terminal stage of differentiation, CD8 ${ }^{+} \mathrm{CD} 28^{-}$Tcells can be expanded indefinitely given the appropriate mixture of cytokines (67). A similar phenomenon has been described for $\mathrm{CD} 4^{+}$. Zhou et al. have shown that $\mathrm{CD} 4^{+}$Tregs constitute an unstable $\mathrm{T}$ cell subset that can be reprogramed into pathogenic effector cytokine-producing T cells. Such $\mathrm{CD}^{+} \mathrm{T}$ cells downregulate their FOXP3 expression, losing suppressive capacity and acquiring an activated-memory phenotype (68). These findings reflect the plasticity of both $\mathrm{CD}^{+}$and $\mathrm{CD} 4^{+}$Treg cells, which can revert their function from suppressors to effector cells. A comprehensive review of $\mathrm{CD}^{+}$Treg in animal transplantation studies can be found in Guillonneau et al., which also emphasizes the identification of PD-1 as a marker of $\mathrm{CD}^{+}$Ts in rodents (69).

Recently, a new subset of $\mathrm{CD}^{+} \mathrm{CD} 122^{+} \mathrm{PD} 1^{+}$Tregs, which produce IL-10, IFN- $\gamma$, and TGF- $\beta$ and suppress $\mathrm{CD}^{+} \mathrm{T}$ cell activation, has been described in mice. Its counterpart in human is still unknown (70). This $\mathrm{CD} 8^{+} \mathrm{cd} 122^{+}$Treg subset was claimed to more potently suppress allograft rejection compared to their $\mathrm{CD} 4{ }^{+} \mathrm{CD} 25^{+}$Tregs (71). Therefore, it appears that $\mathrm{CD} 8^{+} \mathrm{CD} 28^{-}$, $\mathrm{CD}^{+} \mathrm{Qa}-1^{+}, \mathrm{CD}^{+} \mathrm{CD} 103^{+}$, and $\mathrm{CD} 8^{+} \mathrm{CD} 122^{+} \mathrm{PD}-1^{+}$Treg subsets may share the capacity of maintaining homeostasis with an equally heterogeneous population of $\mathrm{CD} 4^{+}$Tregs.

\section{CD8 ${ }^{+}$Ts CELLS IN AUTOIMMUNE DISEASES}

$\mathrm{CD}^{+} \mathrm{T}$ cells can oppose or promote autoimmune disease through activities as suppressor or as cytotoxic effectors (72). Data have been presented that $\mathrm{CD} 8^{+} \mathrm{CD} 28^{-} \mathrm{CD} 56^{-} \mathrm{T}$ cells have suppressive activity in rheumatoid arthritis (RA), preventing the activation of naïve $\mathrm{CD}^{+} \mathrm{T}$ cells and inhibiting their effector function in vivo. When transferred into NOD-SCID chimeras engrafted with human synovial tissue, they suppressed the inflammatory activity in the synovial lesions and inhibited cytokine production (73). Rheumatoid synovitis could also be treated in such chimeras by infusing autologous $\mathrm{CD} 8^{+} \mathrm{CD} 16^{+} \mathrm{T}$ cells, which inhibits the production of IL- $1 \beta$, IFN- $\gamma$, TNF- $\alpha$, and other inflammatory cytokines. Treatment with IL-16 mimicked the effect of the adoptive transfer of Ts and anti-CD16 antibodies abrogated the suppressor effect (74). Similarly, there is evidence that CD8 ${ }^{+}$Ts generated from SLE patients during remission had suppressor activity, while $\mathrm{CD} 8^{+}$obtained during exacerbation of the disease had no such activity (75).

Glatiramer acetate (GA) introduced in the therapy of multiple sclerosis has been shown to induce $\mathrm{CD}^{+} \mathrm{Ts}$, which seem to recognize GA on the cell surface and directly kill $\mathrm{CD}^{+} \mathrm{T}$ cells in a HLA-E-dependent manner (76). Ulcerative colitis and Crohn's disease are other examples of pathological processes in which $\mathrm{CD}^{+} \mathrm{Ts}$ may inhibit proliferation of $\mathrm{CD}^{+} \mathrm{T}$ cell through a TGF- $\beta$-dependent mechanism (77). Intestinal epithelial cells may activate $\mathrm{CD}^{+}$Ts cells, which downregulate IBD, suppressing IgG production (78). In JDM, a one-course administration of humanized anti-CD3 $\mathrm{mAb}$ was claimed to induce the generation of $\mathrm{CD}^{+}{ }^{+} \mathrm{CD} 25^{+} \mathrm{CTLA}-4^{+} \mathrm{FoxP}^{+}$Ts cell, which were able to inhibit the stimulation of $\mathrm{CD}^{+} \mathrm{T}$ cells in in vitro coculture system (79, 80). Accumulating evidence indicates that co-inhibitory molecules, such as CTLA-4, PD1, and BTLA, are negative regulators of immune responses since deficiencies or mutations result in the development of autoimmune diseases. The administration of decoy co-inhibitory receptors, such as CTLA-4.Ig or agonistic antibodies, can suppress the response of self-reactive $\mathrm{T}$ cells in autoimmune diseases.

Abatacept, a fusion protein composed of the Fc fragment of human IgG1 linked to the extracellular domain of CTLA-4, has shown efficacy in a broad spectrum of RA patients from early stage to refractory diseases that are resistant to TNF blockers (81-84).

In addition, Abatacept showed efficacy in patients with juvenile idiopathic arthritis, psoriasis, and SLE. CTLA-4 competes with CD28 on the membrane of activated T cells for binding to B7 molecules (CD80 and CD86) on APC, delivering negative signals which inhibit or terminate $\mathrm{T}$ cell responses.

PD1, another co-inhibitory receptor from the CD28 family, which is expressed on activated T cells (as well as on B cells and monocytes), binds to two ligands of the B7 family, PD-L1 and PD-L2. The ligation of PD-1 with these ligands inhibits $\mathrm{CD} 4^{+}$ and $\mathrm{CD}^{+} \mathrm{T}$ cell proliferation by arresting the cell cycle (85-87). However, in human, PD1 ligation is important to inhibition of cell proliferation and death by apoptosis, rather than to the generation and function of $\mathrm{CD}^{+}$Ts.

BTLA-HVEM pathway is another inhibitory pathway for lymphocyte activation [reviewed in Ref. (78)]. BTLA4, a member of the TNF family, is expressed on $\mathrm{CD}^{+}$and $\mathrm{CD} 8^{+} \mathrm{T}$ cells, NK and NKT cells, as well as on B cells, DC, and macrophages. Its ligand HVEM is also widely expressed on hematopoietic cells, including T cells and APC. Ligation of BTLA induces its tyrosine phosphorylation and SHP-1/SHP-2 association, inhibiting T cell proliferation and IL-2 production. Deficiency of BTLA-HVEM interaction has been shown to be involved in autoimmune diseases, though no clinical trial is yet in progress.

Although current methods of immunotherapy in cancer are largely based on the use of the immune checkpoint inhibitors anti-CTLA-4 and anti-PD-1 antibodies, the major obstacle 
resides in opportunistic autoimmune disorders and associated morbidity resulting from altered immune regulation $(88,89)$.

Other lymphocyte subsets believed to have suppressor function in autoimmune diseases and transplantation include $\mathrm{CD}^{+}{ }^{+} \mathrm{CD} 4^{-} \mathrm{CD}^{-}$(double negative Treg), $\mathrm{CD} 4^{+}$, Valpha14 negative (NKTreg), and gamma/delta Treg cells. It was postulated that there are four modes of Treg function: (1) secretion of inhibitory cytokines such as IL-10 and TGF- $\beta$; (2) granzyme-perforininduced apoptosis of effector T lymphocytes; (3) induction of apoptosis by deprivation of cytokines; and (4) inhibition of DC function $(8,90)$.

Specific recognition of the MHC Class Ib Qa-1bound peptides expressed on activated CD4 T cells by regulatory, cytolytic $\mathrm{CD}^{+}$ $\mathrm{T}$ cells was postulated to prevent autoimmunity in mice (91). A similar function has been attributed to human neuroantigenspecific $\mathrm{CD}^{+}$Treg, which recognize HLA-E-bound peptides and are present in the circulation of patients with multiple sclerosis (92).

A distinct subset of human $\mathrm{CD} 8{ }^{+} \mathrm{CD} 25^{+} \mathrm{FoxP} 3^{+}$Treg seems to be characterized by the expression of the lymphocyte activation gene-3 (LAG-3). The suppressive activity of this subset has been attributed to the secretion of the CC chemokine ligand 4 (CCL4), which interferes with TCR signaling, inhibiting T cell activation. These Tregs can be expanded only from $\mathrm{T}$ cells primed in vivo to a specific antigen by repeated or chronic stimulation in vitro or in vivo, respectively. This indicates that they are adaptive Treg (90).

It has been shown that autologous hematopoietic stem cell transplantation in refractory SLE can induce immunological tolerance to auto-epitopes from nucleosomes by restoring the $\mathrm{CD}^{+}{ }^{+}$oxP $3{ }^{+}$TGF- $\beta$ producing pool of suppressors. These Ts maintained high expression levels of latency-associated peptide (LAP), CD103, PD-L1, and CTLA-4 following transplantation and completely inhibited autoimmunity (93).

Collectively these data indicate the importance of $\mathrm{CD} 8^{+}$Treg in suppressing autoimmune responses and transplant rejection.

\section{CD8 ${ }^{+}$REGULATORY T CELLS IN PERSISTENT VIRAL INFECTION}

The control of virus-specific immune responses may be a mechanism that permits virus persistence. On the other hand, it may also protect the patient from overwhelming $\mathrm{T}$ cell reactivity and destruction of infected tissues (94).

In patients with HIV, it was shown that stimulation of patients' PBMC with HIV-specific antigens induced TGF- $\beta$-producing $\mathrm{CD}^{+}$Treg. These $\mathrm{CD} 8^{+}$Treg suppressed the IFN- $\gamma$ production of $\mathrm{HIV}$-specific and vaccinia virus-specific $\mathrm{CD}^{+} \mathrm{T}$ cells, displaying both a specific and non-specific activity. IL-10-producing CD8 ${ }^{+}$ Treg were also expanded from the peripheral blood of HIVinfected individuals and their frequency seems to be associated with impairment of $\mathrm{CD}^{+}$effector-cytolytic function (95-97).

Distinct populations of $\mathrm{CD}^{+}$Ts were also shown to be present in the blood and liver of patients with chronic HCV infection. Some investigators reported the expansion of CD25-FoxP3-CD8 ${ }^{+}$ Treg that inhibited IFN- $\gamma$ production of $\mathrm{HCV}$-specific $\mathrm{CD} 4^{+}$and $\mathrm{CD} 8^{+}$T cells $v i a$ TGF- $\beta$ production. A population of $\mathrm{HCV}$-specific FoxP $3^{+} \mathrm{CD}^{+}$Treg was also expanded by stimulation with $\mathrm{HCV}$ peptides of PBMC from patients with chronic $\mathrm{HCV}$ infection. These cells inhibited in an antigen non-specific manner, $\mathrm{T}$ cell proliferation via direct T cell-T cell interaction $(98,99)$. Similarly, expansion of virus-specific $\mathrm{CD}^{+} \mathrm{BTLA}^{+} \mathrm{T}$ cells in the liver was observed in patients with chronic HBV infection. These infiltrating regulatory $\mathrm{T}$ cells were antigen specific and suppressed $\mathrm{T}$ cell responses via IL10 secretion (100).

Intra-hepatic IL-10-secreting $\mathrm{CD}^{+}$Treg were described to be present in patients with chronic infection and to suppress IFNproduction of effector $\mathrm{CD}^{+} \mathrm{T}$ cells primed to the same $\mathrm{HCV}$ peptide. Blockade of IL-10 restored effector activity (101).

Herpes viruses, such as EBV, CMV, or HSV, which infect many people worldwide, establish persistent latent infections which, upon reactivation in immunological deficient individuals, are responsible for life threatening episodes of infection. EBV-specific $\mathrm{CD}^{+}{ }^{+} \mathrm{FoxP}^{+}{ }^{+}$Treg cells produce IFN- $\gamma$ and IL-10 but not TGF$\beta$ and suppress $\mathrm{CD}^{+} \mathrm{T}$ cell proliferation in a cell-cell contact manner. Similar mechanisms seem to occur in CMV infection $(102,103)$.

Evidence has been provided that dermal CD $14^{+}$DCs, which express ILT2 and ILT4, prime a fraction of naïve $\mathrm{CD} 8^{+} \mathrm{T}$ cells that produce type 2 cytokines (IL- 4 and IL-5) as opposed to Langerhans cells, which have no ILTs and are highly efficient in priming CD8 ${ }^{+}$CTL. The ILT molecules on dermal DC polarized the $\mathrm{T}$ cell response toward type 2 cytokine producers, as blocking of these receptors enhanced the generation of CTL (104).

Accumulating evidence revealed that viruses have evolved strategies to evade the immune surveillance by inducing specific Tregs. Novel strategy show promising antiviral effects by deletion or inactivation of viral-induced Tregs cells (105).

\section{CONCLUSION}

In light of the multiple pathways which may lead to the activation, generation, and expansion of $\mathrm{T}$ cells with antigen-specific function, it is obvious that therapy based on enhancement or blockade of immune checkpoints used by T cells for interacting with other cells holds promising results. Recombinant ILT3.Fc, CTLA-4. Ig, PD-L1.Ig, or humanized monoclonal antibodies which block effector-ligand interaction are only examples of the numerous agents that may have beneficial effects. However, the success of novel therapies aimed at suppression of autoimmune diseases depends on progress in certain areas:

1. It is apparent that inhibition of immune responses to unidentified autoantigens, deriving from a variety of tissues, calls for a better understanding of signaling pathways activated by ligation of different co-inhibitory checkpoints. This may allow for the design of combination therapy in which agents which act in synergy can be used to inhibit the activation and maturation of effector T helper and cytotoxic cells.

2. Studies on mechanisms' underlying memory of both effectors and suppressors of $\mathrm{T}$ cell immune responses to defined antigens may permit the design of clinical protocols which maintain quiescence in patients in remission.

3. Identification of markers that characterize different stages of $\mathrm{T}$ cell conversion from one effector function to another, 
as exemplified by $\mathrm{CD}^{+}$suppressor and cytotoxic $\mathrm{T}$ cells, as well as of the mechanism of such a transition, is required for patients' monitoring and better timing of therapy.

4. Progress in understanding the way in which cells communicate with each other to perceive endogenous and exogenous signals may open new horizons to immunotherapy of autoimmune diseases and of cancer.

\section{REFERENCES}

1. Ohkura N, Sakaguchi S. Regulatory $\mathrm{T}$ cells: roles of $\mathrm{T}$ cell receptor for their development and function. Semin Immunopathol (2010) 32(2):95-106. doi:10.1007/s00281-010-0200-5

2. Josefowicz S, Rudensky A. Control of regulatory T cell lineage commitment and maintenance. Immunity (2009) 30(5):616-25. doi:10.1016/j. immuni.2009.04.009

3. Shevach E. Mechanisms of foxp3+ T regulatory cell-mediated suppression. Immunity (2009) 30(5):639-45. doi:10.1016/j.immuni.2009.04.010

4. Kuhn A, Beissert S, Krammer PH. CD4 (+) CD25 (+) regulatory T cells in human lupus erythematosus. Arch Dermatol Res (2009) 301(1):71-81. doi:10.1007/s00403-008-0891-9

5. Hippen KL, Merkel SC, Schirm DK, Sieben CM, Sumstad D, Kadidlo DM, et al. Massive ex vivo expansion of human natural regulatory T cells ( $\mathrm{T}(\mathrm{regs})$ ) with minimal loss of in vivo functional activity. Sci Transl Med (2011) 3(83):83ra41. doi:10.1126/scitranslmed.3001809

6. Kapp JA, Bucy PR. CD8+ suppressor T cells resurrected. Hum Immunol (2008) 69(11):715-20. doi:10.1016/j.humimm.2008.07.018

7. Smith TR, Kumar V. Revival of CD8+ Treg-mediated suppression. Trends Immunol (2008) 29(7):337-42. doi:10.1016/j.it.2008.04.002

8. Ligocki AJ, Niederkorn JY. Advances on non-CD4 + Foxp3+ T regulatory cells: $\mathrm{CD} 8+$, type 1 , and double negative $\mathrm{T}$ regulatory cells in organ transplantation. Transplantation (2015) 99(8):1553-9. doi:10.1097/ TP.0000000000000813

9. Gershon RK, Cohen P, Hencin R, Liebhaber SA. Suppressor T cells. J Immunol (1972) 108(3):586-90.

10. Scotto L, Naiyer AJ, Galluzzo S, Rossi P, Manavalan JS, Kim-Schulze S, et al. Overlap between molecular markers expressed by naturally occurring CD4+CD25+ regulatory $\mathrm{T}$ cells and antigen specific CD4+CD25+ and CD8+CD28- T suppressor cells. Hum Immunol (2004) 65(11):1297-306. doi:10.1016/j.humimm.2004.09.004

11. Tang Q, Henriksen KJ, Boden EK, Tooley AJ, Ye J, Subudhi SK, et al. Cutting edge: CD28 controls peripheral homeostasis of CD4+CD25+ regulatory $\mathrm{T}$ cells. JImmunol (2003) 171(1):3348-52. doi:10.4049/ jimmunol.171.7.3348

12. Hoyer KK, Wolslegel K, Dooms H, Abbas AK. Targeting T cell-specific costimulators and growth factors in a model of autoimmune hemolytic anemia. J Immunol (2007) 179(5):2844-50. doi:10.4049/jimmunol.179.5.2844

13. Hoyer KK, Dooms H, Barron L, Abbas AK. Interleukin-2 in the development and control of inflammatory disease. Immunol Rev (2008) 226:19-28. doi:10.1111/j.1600-065X.2008.00697.x

14. Tai X, Cowan M, Feigenbaum L, Singer A. CD28 costimulation of developing thymocytes induces Foxp3 expression and regulatory $\mathrm{T}$ cell differentiation independently of interleukin 2. Nat Immunol (2005) 6(2):152-62. doi:10.1038/ni1160

15. Vuddamalay Y, Attia M, Vicente R, Pomie C, Enault G, Leobon B, et al. Mouse and human $\mathrm{CD} 8(+) \mathrm{CD} 28$ (low) regulatory $\mathrm{T}$ lymphocytes differentiate in the thymus. Immunology (2016) 148(2):187-96. doi:10.1111/imm.12600

16. Cosmi L, Liotta F, Lazzeri E, Francalanci M, Angeli R, Mazzinghi B, et al. Human CD8+CD25+ thymocytes share phenotypic and functional features with CD4+CD25+ regulatory thymocytes. Blood (2003) 102(12):4107-14. doi:10.1182/blood-2003-04-1320

17. Hu D, Ikizawa K, Lu L, Sanchirico ME, Shinohara ML, Cantor H. Analysis of regulatory CD8 T cells in Qa-1-deficient mice. Nat Immunol (2004) 5(5):516-23. doi:10.1038/ni1063

18. Jiang H, Kashleva H, Xu LX, Forman J, Flaherty L, Pernis B, et al. T cell vaccination induces $\mathrm{T}$ cell receptor Vbeta-specific Qa-1-restricted regulatory

\section{AUTHOR CONTRIBUTIONS}

ZX drafted the paper, organized its content, and collected and summarized the data. SH participated in the editorial process, data collection, and analysis. C-CC, Q-YZ, E-RV, and GV performed the critical revision of this article. NS-F is the PI of the study and made the ultimate decision on the manuscript.

CD8(+) T cells. Proc Natl Acad Sci U S A (1998) 95(8):4533-7. doi:10.1073/ pnas.95.8.4533

19. Lu L, Cantor H. Generation and regulation of $\mathrm{CD} 8(+)$ regulatory T cells. Cell Mol Immunol (2008) 5(6):401-6. doi:10.1038/cmi.2008.50

20. Li J, Goldstein I, Glickman-Nir E, Jiang H, Chess L. Induction of TCR Vbeta-specific CD8+ CTLs by TCR Vbeta-derived peptides bound to HLA-E. J Immunol (2001) 167(7):3800-8. doi:10.4049/ jimmunol.167.7.3800

21. Jebbawi F, Fayyad-Kazan H, Merimi M, Lewalle P, Verougstraete JC, Leo O, et al. A microRNA profile of human $\mathrm{CD} 8(+)$ regulatory $\mathrm{T}$ cells and characterization of the effects of microRNAs on Treg cell-associated genes. J Transl Med (2014) 12:218. doi:10.1186/s12967-014-0218-x

22. Filaci G, Fravega M, Negrini S, Procopio F, Fenoglio D, Rizzi M, et al Nonantigen specific CD8+ $\mathrm{T}$ suppressor lymphocytes originate from CD8+CD28- T cells and inhibit both T-cell proliferation and CTL function. Hum Immunol (2004) 65(2):142-56. doi:10.1016/j.humimm.2003.12.001

23. Groux H, Bigler M, de Vries JE, Roncarolo MG. Interleukin-10 induces a long-term antigen-specific anergic state in human CD4+ T cells. J Exp Med (1996) 184(1):19-29. doi:10.1084/jem.184.1.19

24. Filaci G, Bacilieri S, Fravega M, Monetti M, Contini P, Ghio M, et al. Impairment of $\mathrm{CD} 8+\mathrm{T}$ suppressor cell function in patients with active systemic lupus erythematosus. J Immunol (2001) 166(10):6452-7. doi:10.4049/ jimmunol.166.10.6452

25. Vlad G, Cortesini R, Suciu-Foca N. CD8+ T suppressor cells and the ILT3 master switch. Hum Immunol (2008) 69(11):681-6. doi:10.1016/j. humimm.2008.08.286

26. Chang CC, Ciubotariu R, Manavalan JS, Yuan J, Colovai AI, Piazza F, et al. Tolerization of dendritic cells by $\mathrm{T}(\mathrm{S})$ cells: the crucial role of inhibitory receptors ILT3 and ILT4. Nat Immunol (2002) 3:237-43. doi:10.1038/ni760

27. Liu Z, Tugulea R, Cortesini R, Suciu-Foca N. Specific suppression of T helper alloreactivity by allo-MHC class I-restricted CD8+CD28- T cells. Int Immunol (1998) 10(6):775-83. doi:10.1093/intimm/10.6.775

28. Ciubotariu R, Colovai AI, Pennesi G, Liu Z, Smith D, Berlocco P, et al. Specific suppression of human CD4+ Th cell responses to pig MHC antigens by CD8+CD28- regulatory T cells. J Immunol (1998) 161(10):5193-202.

29. Jiang S, Tugulea S, Pennesi G, Liu Z, Mulder A, Lederman S, et al. Induction of MHC-class I restricted human suppressor T cells by peptide priming in vitro. Hum Immunol (1998) 59(11):690-9. doi:10.1016/S0198-8859(98)00073-1

30. Sakaguchi S. Naturally arising CD4+ regulatory t cells for immunologic self-tolerance and negative control of immune responses. Annu Rev Immunol (2004) 24:531-62. doi:10.1146/annurev.immunol.21.120601.141122

31. Manavalan JS, Rossi PC, Vlad G, Piazza F, Yarilina A, Cortesini R, et al. High expression of ILT3 and ILT4 is a general feature of tolerogenic dendritic cells. Transpl Immunol (2003) 11(3-4):245-58. doi:10.1016/ S0966-3274(03)00058-3

32. Liu Z, Tugulea S, Cortesini R, Lederman S, Suciu-Foca N. Inhibition of CD40 signaling pathway in antigen presenting cells by $\mathrm{T}$ suppressor cells. Hum Immunol (1999) 60(7):568-74. doi:10.1016/S0198-8859(99)00044-0

33. Li J, Liu Z, Jiang S, Cortesini R, Lederman S, Suciu-Foca N. T suppressor lymphocytes inhibit NF-kappa B-mediated transcription of CD86 gene in APC. J Immunol (1999) 163(12):6386-92.

34. Chang CC, Vlad G, D’Agati VD, Liu Z, Zhang QY, Witkowski P, et al. BCL6 is required for differentiation of Ig-like transcript 3-Fc-induced CD8+ T suppressor cells. J Immunol (2010) 185(10):5714-22. doi:10.4049/ jimmunol.1001732

35. Gilliet M, Liu YJ. Generation of human CD8 T regulatory cells by CD40 ligand-activated plasmacytoid dendritic cells. J Exp Med (2002) 195(6):695704. doi:10.1084/jem.20011603 
36. Chang CC, Liu Z, Vlad G, Qin H, Qiao X, Mancini DM, et al. Ig-like transcript 3 regulates expression of proinflammatory cytokines and migration of activated T cells. J Immunol (2009) 182(9):5208-16. doi:10.4049/ jimmunol.0804048

37. Colonna M, Nakajima H, Cella M. A family of inhibitory and activating Ig-like receptors that modulate function of lymphoid and myeloid cells. Semin Immunol (2000) 12(2):121-7. doi:10.1006/smim.2000.0214

38. Ravetch JV, Lanier LL. Immune inhibitory receptors. Science (2000) 290(5489):84-9. doi:10.1126/science.290.5489.84

39. Cella M, Dohring C, Samaridis J, Dessing M, Brockhaus M, Lanzavecchia A, et al. A novel inhibitory receptor (ILT3) expressed on monocytes, macrophages, and dendritic cells involved in antigen processing. J Exp Med (1997) 185(10):1743-51. doi:10.1084/jem.185.10.1743

40. Brown D, Trowsdale J, Allen R. The LILR family: modulators of innate and adaptive immune pathways in health and disease. Tissue Antigens (2004) 64(3):215-25. doi:10.1111/j.0001-2815.2004.00290.x

41. Shiroishi M, Tsumoto K, Amano K, Shirakihara Y, Colonna M, Braude $\mathrm{VM}$, et al. Human inhibitory receptors Ig-like transcript 2 (ILT2) and ILT4 compete with CD8 for MHC class I binding and bind preferentially to HLA-G. Proc Natl Acad Sci U S A (2003) 100(15):8856-61. doi:10.1073/ pnas. 1431057100

42. Beinhauser BG, McBride JM, Graf P, Pursch E, Bongers M, Rogy M, et al. Interleukin 10 regulates cell surface and soluble LIR-2 (CD85d) expression on dendritic cells resulting in T cell hyporesponsiveness in vitro. Eur J Immunol (2004) 34(1):74-80. doi:10.1002/eji.200324550

43. Kim-Schulze S, Scotto L, Vlad G, Piazza F, Lin H, Liu Z, et al. Recombinant Ig-like transcript $3-\mathrm{Fc}$ modulates $\mathrm{T}$ cell responses via induction of $\mathrm{Th}$ anergy and differentiation of CD8+ T suppressor cells. J Immunol (2006) 176(5):2790-8. doi:10.4049/jimmunol.176.5.2790

44. Vlad G, D’Agati VD, Zhang QY, Liu Z, Ho EK, Mohanakumar T, et al. Immunoglobulin-like transcript 3-Fc suppresses T-cell responses to allogeneic human islet transplants in hu-NOD/SCID mice. Diabetes (2008) 57(7):1878-86. doi:10.2337/db08-0054

45. Suciu-Foca N, Feirt N, Zhang QY, Vlad G, Liu Z, Lin H, et al. Soluble Ig-like transcript 3 inhibits tumor allograft rejection in humanized SCID mice and T cell responses in cancer patients. J Immunol (2007) 178(11):7432-41. doi:10.4049/jimmunol.178.11.7432

46. Vlad G, Stokes MB, Liu Z, Chang CC, Sondermeijer H, Vasilescu ER, et al. Suppression of xenogeneic graft-versus-host disease by treatment with immunoglobulin-like transcript 3-Fc. Hum Immunol (2009) 70(9):663-9. doi:10.1016/j.humimm.2009.06.001

47. Vlad G, King J, Chang CC, Liu Z, Friedman RA, Torkamani AA, et al. Gene profile analysis of CD8+ ILT3-Fc induced T suppressor cells. Hum Immunol (2011) 72(2):107-14. doi:10.1016/j.humimm.2010.10.012

48. Staal FJ, Luis TC, Tiemessen MM. WNT signaling in the immune system: WNT is spreading its wings. Nat Rev Immunol (2008) 8(8):581-93. doi: $10.1038 /$ nri2360

49. Modiano JF, Johnson LD, Bellgrau D. Negative regulators in homeostasis of naïve peripheral T cells. Immunol Res (2008) 41(2):137-53. doi:10.1007/ s12026-008-8017-1

50. Chang CC, Zhang QY, Liu Z, Clynes RA, Suciu-Foca N, Vlad G. Downregulation of inflammatory microRNAs by Ig-like transcript 3 is essential for the differentiation of human CD8(+) T suppressor cells. J Immunol (2012) 188(7):3042-52. doi:10.4049/jimmunol.1102899

51. Xu Z, Ho S, Chang CC, Liu Z, Li M, Vasilescu ER, et al. ILT3.Fc inhibits the production of exosomes containing inflammatory microRNA in supernatants of alloactivated T cells. Hum Immunol (2014) 75(8):756-9. doi:10.1016/j. humimm.2014.05.006

52. Chen L, Xu Z, Chang CC, Ho S, Liu Z, Vlad G, et al. Allospecific CD8 T suppressor cells induced by multiple MLC stimulation or priming in the presence of ILT3.Fc have similar gene expression profiles. Hum Immunol (2014) 75(2):190-6. doi:10.1016/j.humimm.2013.10.004

53. Stallone G, Pontrelli P, Infante B, Gigante M, Netti GS, Ranieri E, et al. Rapamycin induces ILT3(high)ILT4(high) dendritic cells promoting a new immunoregulatory pathway. Kidney Int (2014) 85(4):888-97. doi:10.1038/ ki.2013.337

54. Manavalan JS, Kim-Schulze S, Scotto L, Naiyer AJ, Vlad G, Colombo PC, et al. Alloantigen specific CD8+CD28- FOXP3+ T suppressor cells induce
ILT3+ ILT4+ tolerogenic endothelial cells, inhibiting alloreactivity. Int Immunol (2004) 16:1055-68. doi:10.1093/intimm/dxh107

55. Cortesini R, Suciu-Foca N. ILT3+ ILT4+ tolerogenic endothelial cells in transplantation. Transplantation (2006) 82(1):S30-2. doi:10.1097/01. tp.0000231437.12890.64

56. Kim-Schulze S, Seki T, Vlad G, Scotto L, Fan J, Colombo PC, et al. Regulation of ILT3 gene expression by processing of precursor transcripts in human endothelial cells. Am J Transplant (2006) 6(1):76-82. doi:10.1111/j.1600-6143.2005.01162.x

57. Gleissner CA, Zastrow A, Klingenberg R, Kluger MS, Konstandin M, Celik S, et al. IL-10 inhibits endothelium-dependent T cell costimulation by up-regulation of ILT3/4 in human vascular endothelial cells. Eur J Immunol (2007) 37(1):177-92. doi:10.1002/eji.200636498

58. Liu J, Liu Z, Witkowski P, Vlad G, Manavalan JS, Scotto L, et al. Rat CD8+ FOXP3 + T suppressor cells mediate tolerance to allogeneic heart transplants, inducing PIR-B in APC and rendering the graft invulnerable to rejection. Transpl Immunol (2004) 13(4):239-47. doi:10.1016/j.trim.2004.10.006

59. Velthuis JH, Unger WW, can der Slik AR, Duinkerken G, Engelse M, Schaapherder AF, et al. Accumulation of autoreactive effector T cells and allo-specific regulatory $\mathrm{T}$ cells in the pancreas allograft of a type 1 diabetic recipient. Diabetologia (2009) 52(3):494-503. doi:10.1007/s00125-008$1237-z$

60. Barbon CM, Davies JK, Voskertchian A, Kelner RH, Brennan LL, Nadler LM, et al. Alloanergization of human T cells results in expansion of alloantigen-specific CD8(+) CD28(-) suppressor cells. Am J Transplant (2014) 14(2):305-18. doi:10.1111/ajt.12575

61. Lin YX, Yan LN, Li B, Wang LL, Wen TF, Zeng Y, et al. A significant expansion of CD8+ CD28- T-suppressor cells in adult-to-adult living donor liver transplant recipients. Transplant Proc (2009) 41(10):4229-31. doi:10.1016/j. transproceed.2009.09.072

62. Colovai AI, Mirza M, Vlad G, Wang S, Ho E, Cortesini R, et al. Regulatory CD8+CD28- T cells in heart transplant recipients. Hum Immunol (2003) 64(1):31-7. doi:10.1016/S1053-2498(02)00777-5

63. Lin YX, Wang LL, Yan LN, Cai P, Li B, Wen TF, et al. Analysis of CD8+CD28T-suppressor cells in living donor liver transplant recipients. Hepatobiliary Pancreat Dis Int (2009) 8(3):241-6.

64. Zheng J, Liu Y, Liu Y, Liu M, Xiang Z, Lam KT, et al. Human CD8+ regulatory T cells inhibit GVHD and preserve general immunity in humanized mice. Sci Transl Med (2013) 5(168):168ra9. doi:10.1126/scitranslmed.3004943

65. Engela AU, Baan CC, Litjens NH, Franquesa M, Betjes MG, Weimar W, et al. Mesenchymal stem cells control alloreactive CD8(+) CD28(-) T cells. Clin Exp Immunol (2013) 174(3):449-58. doi:10.1111/cei.12199

66. Yu Y, Zitzner JR, Houlihan J, Herrera N, Xu L, Miller J, et al. Common gamma chain cytokines promote rapid in vitro expansion of allo-specific human CD8+ suppressor T cells. PLoS One (2011) 6(12):e28948. doi:10.1371/ journal.pone.0028948

67. Betjes MG. Clinical consequences of circulating CD28-negative T cells for solid organ transplantation. Transpl Int (2016) 29(3):274-84. doi:10.1111/ tri. 12658

68. Zhou X, Bailey-Bucktrout SL, Jeker LT, Penaranda C, Martinez-Llordella $M$, Ashby M, et al. Instability of the transcription factor Foxp3 leads to the generation of pathogenic memory T cells in vivo. Nat Immunol (2009) 10(9):1000-7. doi:10.1038/ni.1774

69. Guillonneau C, Picarda E, Anegon I. CD8+ regulatory T cells in solid organ transplantation. Curr Opin Organ Transplant (2010) 15(6):751-6. doi:10.1097/MOT.0b013e32834016d1

70. Li S, Xie Q, Zeng Y, Zou C, Liu X, Wu S, et al. A naturally occurring CD8(+) CD122(+) T-cell subset as a memory-like Treg family. Cell Mol Immunol (2014) 11(4):326-31. doi:10.1038/cmi.2014.25

71. Su J, Xie Q, Xu Y, Li XC, Dai Z. Role of CD8(+) regulatory $\mathrm{T}$ cells in organ transplantation. Burns Trauma (2014) 2(1):18-23. doi:10.4103/2321-3868.126086

72. Gravano DM, Hoyer KK. Promotion and prevention of autoimmune disease by CD8+ T cells. J Autoimmun (2013) 45:68-79. doi:10.1016/j. jaut.2013.06.004

73. Davila E, Kang YM, Park YW, Sawai H, He X, Pryshchep S, et al. Cell-based immunotherapy with suppressor CD8+ T cells in rheumatoid arthritis. J Immunol (2005) 174(11):7292-301. doi:10.4049/jimmunol.174.11.7292 
74. Klimiuk PA, Goronzy JJ, Weyand CM. IL-16 as an anti-inflammatory cytokine in rheumatoid synovitis. J Immunol (1999) 162(7):4293-9.

75. Konya C, Goronzy JJ, Weyand CM. Treating autoimmune disease by targeting CD8(+) T suppressor cells. Expert Opin Biol Ther (2009) 9(8):951-65. doi:10.1517/14712590903020759

76. Tennakoon DK, Mehta RS, Ortega SB, Bhoj V, Racke MK, Karandikar NJ. Therapeutic induction of regulatory, cytotoxic CD8+ T cells in multiple sclerosis. J Immunol (2006) 176(11):7119-29. doi:10.4049/ jimmunol.176.11.7119

77. Ho J, Kurtz CC, Naganuma M, Ernst PB, Cominelli F, Rivera-Nieves JA. CD8+/CD103high T cell subset regulates TNF-mediated chronic murine ileitis. J Immunol (2008) 180(4):2573-80. doi:10.4049/jimmunol.180.4.2573

78. Brimnes J, Allez M, Dotan I, Shao L, Nakazawa A, Mayer L. Defects in CD8+ regulatory $\mathrm{T}$ cells in the lamina propria of patients with inflammatory bowel disease. J Immunol (2005) 174(9):5814-22. doi:10.4049/jimmunol.174. 9.5814

79. Herold KC, Gitelman SE, Masharani U, Hagopian W, Bisikirska B, Donaldson $\mathrm{D}$, et al. A single course of anti-CD3 monoclonal antibody hOKT3gammal(Ala-Ala) results in improvement in C-peptide responses and clinical parameters for at least 2 years after onset of type 1 diabetes. Diabetes (2005) 54(6):1763-9. doi:10.2337/diabetes.54.6.1763

80. Bisikirska B, Colgan J, Luban J, Bluestone JA, Herold KC. TCR stimulation with modified anti-CD3 $\mathrm{mAb}$ expands $\mathrm{CD} 8+\mathrm{T}$ cell population and induces CD8+CD25+ Tregs. JClin Invest (2005) 115(10):2904-13. doi:10.1172/ JCI23961

81. Watanabe N, Nakajima H. Coinhibitory molecules in autoimmune diseases. Clin Dev Immunol (2012) 2012:269756. doi:10.1155/2012/269756

82. Davis PM, Abraham R, Xu L, Nadler SG, Suchard SJ. Abatacept binds to the Fc receptor CD64 but does not mediate complement-dependent cytotoxicity or antibody-dependent cellular cytotoxicity. J Rheumatol (2007) 34(11):2204-10.

83. Genovese MC, Becker JC, Schiff M, Luggen M, Sherrer Y, Kremer J, et al. Abatacept for rheumatoid arthritis refractory to tumor necrosis factor alpha inhibition. N Engl J Med (2005) 353(11):1114-23. doi:10.1056/ NEJMoa050524

84. Kremer JM, Dougados M, Emery P, Durez P, Sibilia J, Shergy W, et al. Treatment of rheumatoid arthritis with the selective costimulation modulator abatacept: twelve-month results of a phase iib, double-blind, randomized, placebo-controlled trial. Arthritis Rheum (2005) 52(8):2263-71. doi:10.1002/ art.21201

85. Agata Y, Kawasaki A, Nishimura H, Ishida Y, Tsubata T, Yagita H, et al. Expression of the PD-1 antigen on the surface of stimulated mouse $\mathrm{T}$ and B lymphocytes. Int Immunol (1996) 8(5):765-72. doi:10.1093/intimm/ 8.5.765

86. Freeman GJ, Long AJ, Iwai Y, Bourque K, Chernova T, Nishimura H, et al. Engagement of the PD-1 immunoinhibitory receptor by a novel B7 family member leads to negative regulation of lymphocyte activation. J Exp Med (2000) 192(7):1027-34. doi:10.1084/jem.192.7.1027

87. Carter L, Fouser LA, Jussif J, Fitz L, Deng B, Wood CR, et al. PD-1:PD-L inhibitory pathway affects both $\mathrm{CD} 4(+)$ and $\mathrm{CD} 8(+) \mathrm{T}$ cells and is overcome by IL-2. Eur JImmunol (2002) 32(3):634-43. doi:10.1002/ 1521-4141(200203)32:3<634::AID-IMMU634>3.0.CO;2-9

88. Kong YC, Flynn JC. Opportunistic autoimmune disorders potentiated by immune-checkpoint inhibitors anti-CTLA-4 and anti-PD-1. Front Immunol (2014) 5:206. doi:10.3389/fimmu.2014.00206

89. Baumeister SH, Freeman GJ, Dranoff G, Sharpe AH. Coinhibitory pathways in immunotherapy for cancer. Annu Rev Immunol (2016) 34:539-73. doi:10.1146/annurev-immunol-032414-112049

90. Peterson RA. Regulatory T-cells: diverse phenotypes integral to immune homeostasis and suppression. Toxicol Pathol (2012) 40(2):186-204. doi:10.1177/0192623311430693

91. Kim HJ, Canton H. Regulation of self-tolerance by Qa-1-restricted CD8(+) regulatory T cells. Semin Immunol (2011) 23(6):446-52. doi:10.1016/j. smim.2011.06.001
92. Sinha S, Boyden AW, Itani FR, Crawford MP, Karandikar NJ. CD8+ T-cells as immune regulators of multiple sclerosis. Front Immunol (2015) 6:619. doi:10.3389/fimmu.2015.00619

93. Zhang L, Bertucci AM, Ramsey-Gordon R, Burt RK, Datta SK. Regulatory $\mathrm{T}$ Cell (Treg) subsets return in patients with refractory lupus following stem cell transplantation, and TGF- $\beta$-producing CD8+ Treg cells are associated with immunological remission of lupus. J Immunol (2009) 183(10):6346-58. doi:10.4049/jimmunol.0901773

94. Billerbeck E, Thimme R. CD8+ regulatory T cells in persistent human viral infections. Hum Immunol (2008) 69(11):771-5. doi:10.1016/j. humimm.2008.07.016

95. Garba ML, Pilcher CD, Bingham AL, Eron J, Frelinger JA. HIV antigens can induce TGF-beta(1)-producing immunoregulatory CD8+ T cells. J Immunol (2002) 168(5):2247-54. doi:10.4049/jimmunol.168.5.2247

96. Elrefaei M, Barugahare B, Ssali F, Mugyenyi P, Cao H. HIV-specific IL-10positive CD8+ T cells are increased in advanced disease and are associated with decreased HIV-specific cytolysis. JImmunol (2006) 176(2):1274-80. doi:10.4049/jimmunol.176.2.1274

97. Elrefaei M, Ventura FL, Baker CA, Clark R, Bangsberg DR, Cao H. HIV-specific IL-10-positive CD8+ T cells suppress cytolysis and IL-2 production by CD8+ T cells. J Immunol (2007) 178(5):3265-71. doi:10.4049/ jimmunol.178.5.3265

98. Alatrakchi N, Graham CS, van der Vliet HJ, Sherman KE, Exley MA, Koziel MJ. Hepatitis C virus (HCV)-specific CD8+ cells produce transforming growth factor beta that can suppress HCV-specific T-cell responses. J Virol (2007) 81(11):5882-92. doi:10.1128/JVI.02202-06

99. Billerbeck E, Blum HE, Thimme R. Parallel expansion of human virus-specific FoxP3- effector memory and de novo-generated FoxP3+ regulatory CD8+ $\mathrm{T}$ cells upon antigen recognition in vitro. J Immunol (2007) 179(2):1039-48. doi:10.4049/jimmunol.179.2.1039

100. Wang H, Wu B, Li L, Hu L, Lin J, Jiang C, et al. Hepatic expansion of virus-specific CD8+BTLA+ T cells with regulatory properties in chronic hepatitis B virus infection. Cell Immunol (2016). doi:10.1016/j.cellimm.2016.10.002

101. Accapezzato D, Francavilla V, Paroli M, Casciaro M, Chircu LV, Cividini A, et al. Hepatic expansion of a virus-specific regulatory $\mathrm{CD} 8(+) \mathrm{T}$ cell population in chronic hepatitis C virus infection. J Clin Invest (2004) 113(7):963-72. doi:10.1172/JCI200420515

102. Nordstrom I, Nurkkala M, Collins LV, Eriksson K. CD8+ T-cells suppress antigen-specific and allogeneic $\mathrm{CD} 4+\mathrm{T}$-cell responses to herpes simplex virus type 2-infected human dendritic cells. Viral Immunol (2005) 18(4):616-26. doi:10.1089/vim.2005.18.616

103. Popescu I, Macedo C, Abu-Elmagd K, Shapiro R, Hua Y, Thomson AW, et al. EBV-specific CD8+ T cell reactivation in transplant patients results in expansion of CD8+ type-1 regulatory T cells. Am J Transplant (2007) 7(5):1215-23. doi:10.1111/j.1600-6143.2007.01740.x

104. Banchereau J, Zurawski S, Thompson-Snipes L, Blanck JP, Clayton S, Munk A, et al. Immunoglobulin-like transcript receptors on human dermal CD14+ dendritic cells act as a CD8-antagonist to control cytotoxic T cell priming. Proc Natl Acad Sci U S A (2012) 109(46):18885-90. doi:10.1073/ pnas. 1205785109

105. Holderried TA, Lang PA, Kim HJ, Cantor H. Genetic disruption of CD8+ Treg activity enhances the immune response to viral infection. Proc Natl Acad Sci U S A (2013) 110(52):21089-94. doi:10.1073/pnas.1320999110

Conflict of Interest Statement: The authors declare that the research was conducted in the absence of any commercial or financial relationships that could be construed as a potential conflict of interest.

Copyright $\odot 2016 \mathrm{Xu}$, Ho, Chang, Zhang, Vasilescu, Vlad and Suciu-Foca. This is an open-access article distributed under the terms of the Creative Commons Attribution License (CC BY). The use, distribution or reproduction in other forums is permitted, provided the original author(s) or licensor are credited and that the original publication in this journal is cited, in accordance with accepted academic practice. No use, distribution or reproduction is permitted which does not comply with these terms. 